\title{
EFFECT OF BURSECTOMY AND THYMECTOMY ON PASTEURELLA MULTOCIDA INFECTION IN CHICKENS
}

\author{
T. BABA, T. ANDO AND M. NuKINA \\ Department of Animal Microbiology, College of Agriculture, \\ University of Osaka Prefecture, Mozu-Umemachi, Sakai, Osaka, Japan
}

IT was shown by Ando and Baba (1969) that antiserum obtained by immunising chickens with Pasteurella multocida did not inhibit the growth of $P$. multocida in vitro, and failed to produce passive immunity in normal chickens.

The present paper describes investigations into the immune mechanisms of chickens against $P$. multocida involving either the removal of the bursa of Fabricius, which controls humoral immunity, or the thymus, which controls cellular immunity.

Little is known about the immune responses of chickens to $P$. multocida. Among the published reports of the effects of bursectomy or thymectomy on the immunity of chickens to bacterial or mycoplasma infections are those by Chang, Rheins and Winter (1959), Perek and Drill (1962), Okuyama (1967), Nakamura and Hashimoto (1968), Sadler and Edgar (1969), Brownell, Sadler and Fanelli (1970), Cheville and Richards (1971), Panigrahi et al. (1972), Yamaguchi et al. (1973) and Vardaman et al. (1973). This is the first report of the use of similar methods in the study of immunity of chickens to P. multocida.

\section{MATERIALS AND METHODS}

Chickens. A non-inbred Hy-line strain of White Leghorns from a commercial hatchery was used.

Bacterial strain. The virulent $P$. multocida strain P1059, serotype $8: A$, was used. It had a minimal lethal dose (MLD) of 560 viable cells when introduced by the intravenous route.

Bursectomy and thymectomy. Surgical bursectomy (SB) was performed on the day of hatching. Hormonal bursectomy (HB) was performed by dipping 2-day-old embryonated eggs into $2 \%$ testosterone propionate (TP; Sigma Chemical Company, PO Box 14508, St Louis, Missouri 63178, USA) in absolute ethanol for $5 \mathrm{~s}$.

Surgical thymectomy (ST) was performed as previously described (Baba, 1975). The effects of the thymectomies were checked by macrophage migration-inhibition tests.

$X$-irradiation. The following conditions were used: $200 \mathrm{kV}, 15 \mathrm{~mA}$ with $0.5-\mathrm{mm} \mathrm{Al}$ and $0 \cdot 3-\mathrm{mm} \mathrm{Cu}$ filters. The chickens received $500 \mathrm{R}$ at a dose rate of $50 \mathrm{R}$ per min. on the day after SB or ST.

Preparation of formalin-killed vaccine $(F K V)$. Organisms grown in 18-h brain-heart infusion agar cultures were centrifuged and washed twice in saline. They were then suspended in buffered saline containing $0 \cdot 2 \%$ formalin to give $100 \mathrm{mg}$ (wet weight) per $\mathrm{ml}$. The suspension was kept in a waterbath at $37^{\circ} \mathrm{C}$ for 2 days and then stored at $5^{\circ} \mathrm{C}$.

Immunisation and challenge. Four-week-old chickens were immunised subcutaneously with $0.5 \mathrm{ml}$ of FKV. Seven days later a second dose of $0.2 \mathrm{ml}$ of FKV was administered intravenously.

Received 25 Aug. 1977; revised version accepted 4 Jan. 1978.

J. MED. MICROBIOL.—VOL. 11 (1978) 
Two weeks after the second immunising dose the chickens, together with unimmunised controls, were inoculated intravenously with $1000 \mathrm{MLD}$ of the homologous strain. The protective effects were assessed by observing the birds for at least 2 weeks after challenge.

Agglutination test. Serum samples were collected from the chickens on the day before challenge. The antigens were prepared by $\mathrm{HCl}$ treatment of $P$. multocida strain $\mathrm{P} 1059$, as described by Namioka and Murata (1961). Agglutinins to $P$. multocida were determined by a microtitration procedure.

Disk electrophoresis. A 1 in 25 dilution of serum collected on the day before challenge was used and polyacrylamide electrophoresis performed by a modification of the methods of Ornstein (1964) and Davis (1964). Electrophoresis was maintained at $5 \mathrm{~mA}$ per tube with the gel tubes immersed in tris-glycine buffer $(p \mathrm{H} \mathrm{8.6)}$. After electrophoresis for $5 \mathrm{~h}$, the gels were removed from the tubes and stained for protein in $1 \%$ amino black for $30 \mathrm{~min}$. Destaining was carried out with $7 \%$ acetic acid. Densitometer scans were obtained with a Fujiox FD-A1V densitometer (Fuji Riken Co. Ltd, Tokyo, Japan).

Macrophage migration-inhibition test. An adaptation of the methods of George and Vaughan (1962) was used. Capillary tubes (microhaematocrit, $1.1 \times 75 \mathrm{~mm}$ ) were part-filled with peritoneal-cell suspension from immunised or normal chickens, sealed with a gas burner, and then centrifuged at 800 r.p.m. for $10 \mathrm{~min}$.

The tubes were broken at the cell-fluid interface, and the cell-containing portions placed in small glass dishes. The dishes were filled with Eagle's medium containing chicken serum $20 \%$ and incubated for $24 \mathrm{~h}$ in a $\mathrm{CO}_{2}$ incubator at $37^{\circ} \mathrm{C}$. The distance of macrophage migration from the edge of the tube was measured with an ocular micrometer as described by Morita and Soekawa (1972).

\section{RESULTS}

\section{Effects of surgical bursectomy on protection conferred by immunisation}

It was reported by Baba (1977), Heddleston, Gallagher and Rebers (1970) and Alexander and Soltys (1973) that FKV immunisation gave protection in only $57-73 \%$ of untreated chickens.

In the experiments reported here (table I) $63 \%$ of the chickens immunised

TABLE I

Effect of surgical bursectomy and X-irradiation on the immunisation of chickens against Pasteurella multocida

\begin{tabular}{lc|cc}
\hline $\begin{array}{c}\text { Treatment before } \\
\text { immunisation with } \\
\text { FKV }\end{array}$ & $\begin{array}{c}\text { Number of } \\
\text { chickens }\end{array}$ & $\begin{array}{c}\text { Number of } \\
\text { chickens that } \\
\text { survived } \\
\text { challenge }\end{array}$ & $\begin{array}{c}\text { Percentage } \\
\text { survivors }\end{array}$ \\
\hline $\begin{array}{l}\text { Surgical bursectomy } \\
\begin{array}{l}\text { Surgical bursectomy+ } \\
\text { X-irradiation }\end{array}\end{array}$ & 30 & 19 & 63 \\
$\begin{array}{l}\text { X-irradiation } \\
\text { None }\end{array}$ & 5 & 22 & 63 \\
\hline Non-immunised controls & 30 & 4 & 80 \\
\hline
\end{tabular}

$\mathrm{FKV}=$ formalin-killed vaccine.

For details of treatment, immunisation and challenge see Materials and methods. 
after SB survived challenge; this was similar to the survival rate in a control group of immunised normal chickens and to that in the immunised but otherwise untreated chickens referred to above. A survival rate of $63 \%$ was also recorded in the group of immunised chickens that after SB had received Xirradiation to destroy any bursa-derived cells that may have been released into the peripheral tissue in the embryonal stage (SBX chickens). It may therefore be concluded that this treatment resulted in no loss of protection.

\section{Effects of hormonal bursectomy on protection}

The immune response of B cell-deficient chickens was studied by performing $\mathrm{HB}$ with testosterone to inhibit the development of the bursa of Fabricius in the embryonal stage. The results are given in table II. Like the immunised SB group, the immunised HB group was no less protected against challenge than were immunised normal chickens.

\section{Effects of surgical thymectomy on protection}

Having investigated the role of humoral immunity in conferring protection against infection with $P$. multocida, the involvement of the thymus-dependent immune system, i.e., cellular immunity, was studied.

The immune response of a group of chickens subjected to ST on hatching and then immunised, was compared with that of a similarly treated group that in addition, when 2 days old, received X-irradiation to destroy the thymusderived cells in the circulation before immunisation (STX chickens).

As shown in table III, the survival rate in the immunised normal group was about as usual (73\%) while the survival rates in the ST and STX groups were $31 \%$ and $25 \%$, respectively. Thus there was a highly significant difference $(\mathrm{P}<0.001)$ between the survival rate of the immunised normal group and that of the immunised ST and STX groups; the latter groups also appeared significantly different from the immunised SB and SBX groups in terms of survival rate after challenge (see table I).

TABLE II

Effect of hormonal bursectomy on the immunisation of chickens against $P$. multocida

\begin{tabular}{lc|cc}
\hline $\begin{array}{c}\text { Treatment before } \\
\text { immunisation with } \\
\text { FKV }\end{array}$ & $\begin{array}{c}\text { Number of } \\
\text { chickens }\end{array}$ & $\begin{array}{c}\text { Number of } \\
\text { chickens that } \\
\text { survived } \\
\text { challenge }\end{array}$ & $\begin{array}{c}\text { Percentage } \\
\text { survivors }\end{array}$ \\
\hline Hormonal bursectomy & 8 & 6 & 75 \\
None & 8 & 5 & 63 \\
\hline Non-immunised controls & 10 & 0 & 0 \\
\hline
\end{tabular}

$\mathrm{FKV}=$ formalin-killed vaccine.

For details of treatment, immunisation and challenge see Materials and methods. 
TABLE III

Effect of surgical thymectomy on the immunisation of chickens against $P$. multocida

\begin{tabular}{lc|cc}
\hline $\begin{array}{c}\text { Treatment before } \\
\text { immunisation with } \\
\text { FKV }\end{array}$ & $\begin{array}{c}\text { Number of } \\
\text { chickens }\end{array}$ & $\begin{array}{c}\text { Number of } \\
\text { chickens that } \\
\text { survived } \\
\text { challenge }\end{array}$ & $\begin{array}{c}\text { Percentage } \\
\text { survivors }\end{array}$ \\
\hline $\begin{array}{l}\text { Surgical thymectomy } \\
\begin{array}{l}\text { Surgical thymectomy+ } \\
\text { X-irradiation }\end{array}\end{array}$ & 35 & 11 & 31 \\
$\begin{array}{l}\text { X-irradiation } \\
\text { None }\end{array}$ & 10 & 6 & 25 \\
\hline Non-immunised controls & 33 & 6 & 60 \\
\hline
\end{tabular}

FKV $=$ formalin-killed vaccine.

For details of treatment, immunisation and challenge see Materials and methods.

\section{Effects of a combination of bursectomy and thymectomy on protection}

Neither SB nor HB appeared to affect the immunity of the chickens to infection with $P$. multocida. On the other hand, ST caused a significant loss in protective immunity. The effect of removing both the bursa of Fabricius and the thymus from the birds was then studied.

It may be seen (table IV) that chickens treated in this way were less immune than the immunised normal chickens $(P=0.05)$.

\section{TABLE IV}

Effect of surgical thymectomy and hormonal bursectomy on the immunisation of chickens against $\boldsymbol{P}$. multocida

\begin{tabular}{lc|cc}
\hline $\begin{array}{c}\text { Treatment before } \\
\text { immunisation with } \\
\text { FKV }\end{array}$ & $\begin{array}{c}\text { Number of } \\
\text { chickens }\end{array}$ & $\begin{array}{c}\text { Number of } \\
\text { chickens that } \\
\text { survived } \\
\text { challenge }\end{array}$ & $\begin{array}{c}\text { Percentage } \\
\text { survivors }\end{array}$ \\
\hline $\begin{array}{l}\text { Thymectomy+hormonal } \\
\text { bursectomy }\end{array}$ & 11 & 2 & 18 \\
None & 14 & 8 & 57 \\
\hline Non-immunised controls & 15 & 0 & 0 \\
\hline
\end{tabular}

FKV = formalin-killed vaccine.

For details of treatment, immunisation and challenge see Materials and methods. 
TABLE V

Effect of bursectomy and thymectomy on chickens immunised against $P$. multocida as shown by the agglutination and macrophage migration-inhibition tests

\begin{tabular}{l|cc}
\hline $\begin{array}{c}\text { Treatment before } \\
\text { immunisation with } \\
\text { FKV }\end{array}$ & $\begin{array}{c}\text { Mean agglutinin } \\
\text { titres }\left(\log _{2}\right)\end{array}$ & $\begin{array}{c}\text { Macrophage migration } \\
\text { inhibition }(\%)\end{array}$ \\
\hline Surgical bursectomy & $<1$ & $33 \cdot 7$ \\
$\begin{array}{l}\text { Surgical bursectomy+ } \\
\text { X-irradiation }\end{array}$ & $<1$ & $43 \cdot 4$ \\
Hormonal bursectomy & $<1$ & $58 \cdot 0$ \\
Surgical thymectomy & 4 & $5 \cdot 5$ \\
Surgical thymectomy+ & 3 & $7 \cdot 3$ \\
$\quad$ X-irradiation & $<1$ & $44 \cdot 2$ \\
\hline None & $<$ & $17 \cdot 1$ \\
\hline Non-immunised controls & $<$ \\
\hline
\end{tabular}

$\mathrm{FKV}=$ formalin-killed vaccine.

For details of treatment and immunisation see Materials and methods.

\section{Development of humoral and cellular immunity in bursectomised or thymectomised immune chickens}

The immunised SB, SBX, HB, ST and STX chickens were examined for the development of humoral and cellular immunity as revealed by the agglutination test, macrophage migration-inhibition test (MIT) with peritoneal macrophages, and the immunoglobulin pattern obtained by disk electrophoresis. The results are given in table $\mathrm{V}$ and in the figure.

In the immunised SB, SBX and HB groups no production of agglutinins was observed and the patterns obtained by disk electrophoresis showed no increase in immunoglobulins. The MIT, however, showed that migration-inhibition in these groups was almost as intense as that in the immunised normal group.

On the other hand, the development of agglutinins in the immunised ST and STX groups was similar to that in the immunised normal chickens, and the patterns obtained by disk electrophoresis showed an increase in the immunoglobulins of these two groups, but no macrophage migration-inhibition was observed.

\section{Discussion}

Neither the agglutinin titres nor the immunoglobulin levels increased in chickens that received SB or HB and were then immunised. The MIT showed that migration-inhibition in these groups of chickens was comparable to that in immunised normal chickens. These findings indicate that immunity was associated with the thymus T-cell system. Because no loss in the protective 
(1)

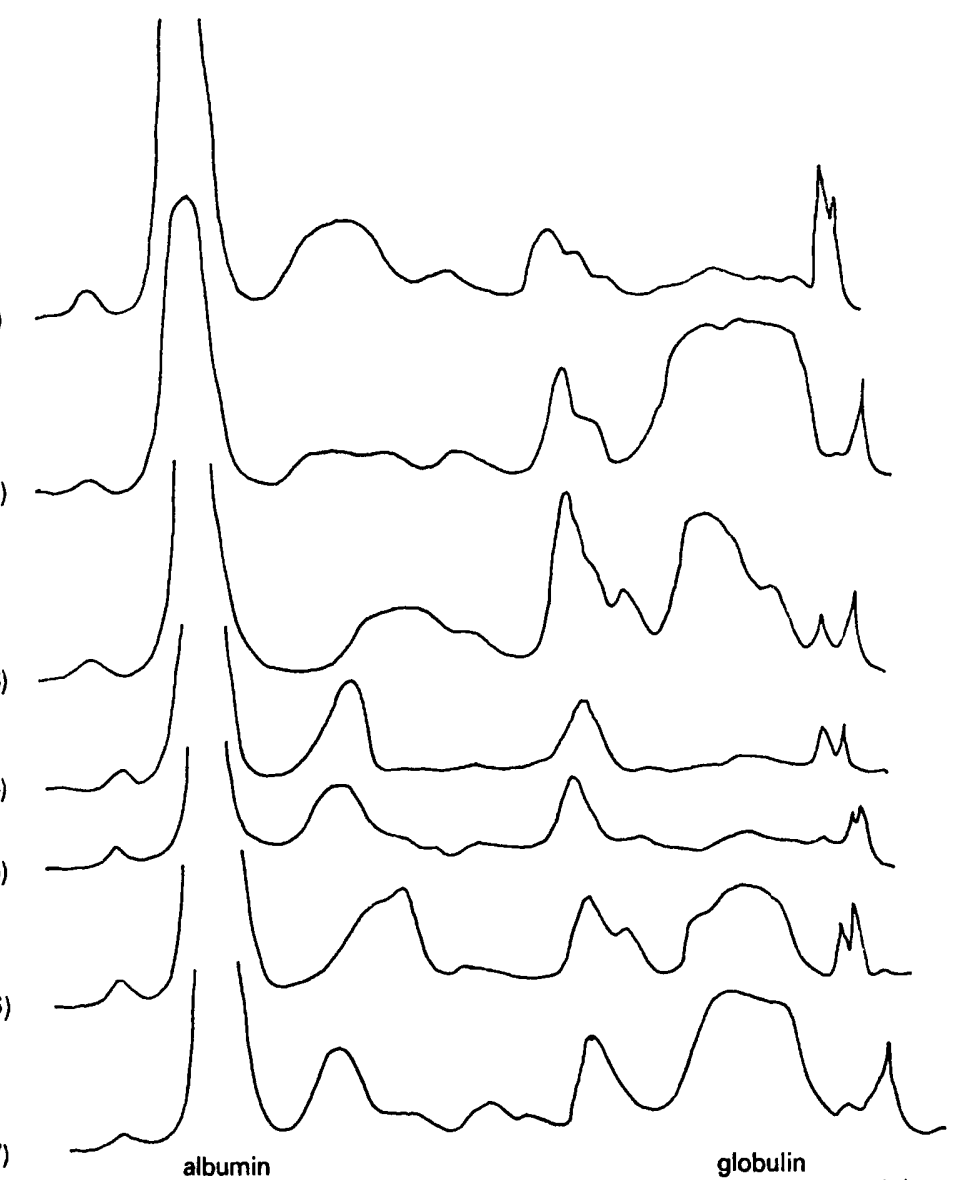

$(+)$

$(-)$

FIGURE-Immunoglobulin patterns obtained by disk electrophoresis of serum taken on the day before challenge from control groups of chickens and from groups given various treatments before immunisation against Pasteurella multocida: (1) = untreated unimmunised controls; (2) $=$ untreated but immunised controls; $(3)=\mathrm{X}$-irradiated; $(4)=$ surgically bursectomised; $(5)=$ surgically bursectomised and X-irradiated; $(6)=$ surgically thymectomised; (7) = surgically thymectomised and X-irradiated.

effect of immunisation was observed in the SB and HB groups, it would seem that humoral immunity plays no part in protection produced by immunisation against $P$. multocida in chickens.

The production of agglutinins in chickens that had been thymectomised and then immunised was similar to that in immunised normal chickens, and the immunoglobulin levels were strikingly elevated. It was therefore obvious that in these birds the humoral immune system was functioning normally. The MIT, however, showed that no migration-inhibition occurred and thymus (T-cell) dependent, cell-mediated immunity was absent. In ST groups the protection produced by immunisation against $P$. multocida was strikingly low. It may therefore be concluded that the immunity conferred by active immunisation against $P$. multocida infection in the chicken is dependent on the thymus 
T-cell system. Our results are consistent with those of Heddleston, Rebers and Ritchie (1966), who failed to protect mice passively with serum from rabbits immunised with $P$. multocida strain P1059.

\section{SUMMARY}

The effects of various treatments on the immune response of chickens to vaccine prepared from Pasteurella multocida strain P1059 were investigated. The treatments, given on or before the day of hatching, consisted of surgical bursectomy (SB), hormonal bursectomy (HB), surgical thymectomy (ST) and $\mathrm{X}$-irradiation (X).

In chickens subjected to SB, SBX or $\mathrm{HB}$ before vaccination, the production of agglutinin and immunoglobulin was impaired, but the production of resistance against challenge was not. In chickens subjected to ST or STX before vaccination, the production of agglutinin and immunoglobulin was unimpaired, but the production of resistance against challenge was diminished. Protection was therefore thymus-dependent.

\section{REFERENCES}

AleXander, A. M. AND Soltys, M. A. 1973. Relationship of serum agglutinins to protective immunity produced in turkeys immunised against fowl cholera. J. comp. Path., 83, 191 .

Ando, T. AND BABA, T. 1969. Studies on the host resistance against Pasteurella multocida; humoral resistance. Jap. J. vet. Sci., Suppl., 31, 26.

BABA, T. 1975. Thymectomy of chicks. In Methods of experimental immunology (IV), Japanese Society for Immunology, Kanazawa, p. 1081.

BABA, T. 1977. Immunogenic activity of a ribosomal fraction obtained from Pasteurella multocida. Infect. Immun., 15, 1.

Brownell, J. R., SAdler, W. W. AND Fanelli, M. J. 1970. Role of bursa of Fabricius in chicken resistance to Salmonella typhimurium. Avian Dis., 14, 142.

Chang, T. S., Rheins, M. S. AND Winter, A. R. 1959. The significance of the bursa of Fabricius of chickens in antibody production. Part III. Resistance to Salmonella typhimurium infection. Poult. Sci., 38, 174.

Cheville, N. F. AND Richards, W. D. 1971. The influence of thymic and bursal lymphoid systems in avian tuberculosis. Am. J. Path., 64, 97.

DAvIS, B. J. 1964 . Disc electrophoresis. II. Method and application to human serum proteins. Ann. N.Y. Acad. Sci., 121, 404.

George, M. AND Vaughan, J. H. 1962. In vitro cell migration as a model for delayed hypersensitivity. Proc. Soc. exp. Biol. Med., 111, 514.

Heddleston, K. L., Gallagher, J. E. and Rebers, P. A. 1970. Fowl cholera; immune response in turkeys. Avian Dis., 14, 626.

Heddleston, K. L., Rebers, P. A. ANd Ritchie, A. E. 1966. Immunizing and toxic properties of particulate antigens from two immunogenic types of Pasteurella multocida of avian origin. J. Immun., 96, 124.

Morita, C. AND SoEKaWA, M. 1972. Effect of sinectomy and bursectomy on migration inhibition test of splenic cells in chickens. Poult. Sci., 51, 1133.

NAKAMURA, T. AND HASHMOTO, H. 1968. Effects of Salmonella senftenberg injection on chicks hatched from eggs in treatment of testosterone propionate. J. Fac. fish anim. Husb., Hiroshima Univ., 7, 217.

Namioka, S. AND Murata, M. 1961. Serological studies on Pasteurella multocida. II. Characteristics of somatic (O) antigen of the organism. Cornell Vet., 51, 507. 
OxuYAMA, S. 1967. Immune response of bursectomized and thymectomized chickens. Saishin-Igaku, 22, 1965.

OrNSteIn, L. 1964. Disc electrophoresis. I. Background and theory. Ann. N.Y. Acad. Sci., $121,321$.

Panigrahi, D., Panigrahi, A. H., Fauser, I. S., Mallmann, V. H. and Waxler, G. L. 1972. Effect of thymectomy, thymectomy and $\mathrm{X}$-irradiation, and $\mathrm{X}$-irradiation alone on experimentally induced tuberculosis in the chicken. Am. J. vet. Res., 33, 1857.

PEREK, M. AND DrILL, A. E. 1962. The role of the bursa of Fabricius in developing immunity in chickens treated with Salmonella typhimurium and Spirochaeta gallinarum. Br. vet.J., 118, 390.

SAdLeR, R. AND Edgar, S. A. 1969. Importance of the bursa of Fabricius in resistance to disease. 2. Resistance to two bacterial diseases. Poult. Sci., 48, 1090.

Vardaman, T. H., Landreth, K., Whatley, S., Dreesen, L. J. and Glick, B. 1973. Resistance to Mycoplasma synoviae is bursal dependent. Infect. Immun., 8, 674.

Yamaguchi, Y., Suzuki, Y., Uenohara, K., Yanagisawa, R. and Tsukuda, I. 1973. The mechanism of cellular immunity in avian tuberculosis. Proc. 3rd A. Meeting Jap. Soc. Immun., p. 192. 